\title{
Carbonation of high-calcium fly ashes and its potential for carbon dioxide removal in coal fired power plants
}

Agnieszka Ćwik ${ }^{* 1,2.3}$, Ignasi Casanova, ${ }^{1,2}$, Kwon Rausis $^{1,2}$, Nikolaos Koukouzas ${ }^{4}$, Katarzyna Zarębska $^{3}$

${ }^{1}$ UPC Universitat Politècnica de Catalunya, Institute of Energy Technologies

${ }^{2}$ Barcelona Research Center in Multiscale Science and Engineering

Campus Diagonal-Besòs, 08930 Barcelona, Spain

${ }^{3}$ AGH University of Science and Technology, Faculty of Energy and Fuels

Al. Mickiewicza 30, 30-059 Cracow, Poland

${ }^{4}$ Centre for Research and Technology Hellas (CERTH), Chemical Process and Energy Resources Institute (CPERI)

52 Egialias Str., 15125 Maroussi, Athens, Greece

*agnieszka.cwik@upc.edu

ABSTRACT

Carbonation of industrial wastes rich in earth-alkali oxides is found to have a significant potential for $\mathrm{CO}_{2}$ sequestration. This process opens new perspectives not only for carbon dioxide mitigation, but also for the valorization and new applications of industrial waste materials from coal-burning power 
plants. In this study, mineral carbonation of high-calcium fly ash is investigated under dry and moist conditions in a continuous flow reactor during up to 2 hours, at temperatures ranging from 160 to $290{ }^{\circ} \mathrm{C}$ and $\mathrm{CO}_{2}$ pressures between 1 and 6 bar. A comprehensive charaterization of treated and untreated samples was carried out before and after carbonation using X-ray diffraction, X-ray fluorescence spectroscopy, thermogravimetric analysis, infrared spectroscopy and scanning electron microscopy. The maximum sequestration capacity achieved was $117.7 \mathrm{~g} \mathrm{CO}_{2} / \mathrm{kg}$ fly ash (48.14 \% carbonation efficiency) under dry conditions. Results showed that increasing the pressure and temperature enhances the process of carbonation, as well as the presence of moderate amounts of water vapor in the $\mathrm{CO}_{2}$ gas flow. Newly formed carbonates were always present in the treated samples. This study shows that about $21 \%$ of all $\mathrm{CO}_{2}$ emissions of a coal-burning power plant could potentially be sequestered as carbonates.

\section{KEYWORDS}

Carbon dioxide, industrial waste, gas-solid carbonation, coal fly ash

\section{Introduction}

The International Energy Agency (IEA) states that 4000 Mt of the world total primary energy demand and $45.9 \%$ of the world carbon dioxide emissions from fuel combustion come from coal processing. Additionally, forecasts predict these numbers to increase (International Energy Agency, 2017). In 2010, the worldwide production of coal combustion waste products was approximately 780 million metric tonnes, $70 \%$ of that value corresponding to fly ashes (Heidrich et al., 2013). Fly ashes, the inorganic residue remaining after coal combustion, are generally divided into two groups according to their chemical composition: siliceous fly ashes, produced mainly by burning of bituminous or anthracite coals with more than $70 \mathrm{wt} \%$ of $\mathrm{SiO}_{2}+\mathrm{Al}_{2} \mathrm{O}_{3}+\mathrm{Fe}_{2} \mathrm{O}_{3}$, and high-calcium fly ashes (HCFA), resulting from burning lignite or sub-bituminous coals, with contents of $\mathrm{SiO}_{2}+\mathrm{Al}_{2} \mathrm{O}_{3}+\mathrm{Fe}_{2} \mathrm{O}_{3}$ between 50 and $70 \%$ (ASTM 
C618-05, 2005) and >10 wt\% CaO. In Europe, more than 50\% of the total production of fly ash is HCFA (Feuerborn, 2011).

The utilization rate in EU of the siliceous fly ashes amounts to $80 \%$ (commonly as concrete admixtures), and $20 \%$ for the HCFA (Papayianni et al., 2009). The production of coal ash is constantly growing and disposal of the large amount of ash waste is a considerable environmental problem. A description of fly ash utilization technologies is summarized in Ahmaruzzaman (2010). Carbon Capture, Utilization and Storage (CCUS) technologies are perceived to have a high potential for lowering greenhouse gas emissions from the existing and newly designed power stations. Among these, mineral carbonation can be considered as a safe, permanent and environmentally friendly carbon storage technology (Bobicki et al., 2012; Lackner et al., 1995). The process is thermodynamically favorable and imitates natural weathering of rocks (Huijgen, 2003; Matter et al., 2016; Matter and Kelemen, 2009). Calcium and/or magnesium bearing minerals are suitable for $\mathrm{CO}_{2}$ fixation and utilization. Industrial wastes from coal-burning power plants can also be used for CCUS through carbonation, as they can contain calcium and/or magnesium oxides or silicate mineral residues (Fernández-Bertos et al., 2004).

The process of carbonation is a simple 2-step reaction, including hydration of the $\mathrm{Ca}$ and/or $\mathrm{Mg}$ followed by carbonation of their respective hydroxides (Mazzotti et al., 2005). Carbonation occurs in nature at very low kinetic rates; following analogous reaction mechanisms, the industrial utilization of anthropogenic carbon dioxide requires a substantial increase of the reaction rates, but current approaches to acceleration of this process are either too costly or consume too much energy (Krevor and Lackner, 2009). Industrial wastes have a significant potential for the carbonation process as they are cheap, easily accessible and usually they do not need any pretreatment (Mazzella et al., 2016; Reynolds et al., 2014; Tamilselvi Dananjayan et al., 2016). Among these, HCFA (despite their complex chemical and mineralogical composition) are suitable substrate materials due to their high contents of calcium oxide (>10\%). This calcium enrichment, however, prevents their use in construction and cementitious materials. The problem associated with the utilization of HCFA in cement arises from their high lime content: during cement hydration, additional pozzolanic reactions can be triggered by $\mathrm{CaO}$ in the presence of water; as a 
consequence, concrete properties may change affecting the durability of this construction material. The significant variability of lime contents in HCFA is a matter of a great concern when the possibility of using this material as a cement admixture is considered (Papayianni, 1993). As a consequence, most HCFA waste materials are currently collected in storage ponds (Ahmaruzzaman, 2010). At coal fired power plants, both carbon dioxide and fly ash are produced on site. Therefore, if the carbonation reactor is placed close to the power plant, the cost of the carbon storage could be reduced, since there is no need for the $\mathrm{CO}_{2}$ or fly ash transportation (Reynolds et al., 2014; Wee, 2013).

Carbonation of natural minerals and industrial waste has recently received a renewed interest, but many challenges regarding this process stay unresolved (Klein and Garrido, 2011; Kwon, 2011; Mazzella et al., 2016; Tamilselvi Dananjayan et al., 2016; Uliasz-Bochenczyk, 2007). When it comes to carbonation of fly ashes, different routes have been studied: gas-solid direct carbonation, aqueous route, suspension$\mathrm{CO}_{2}$, two step indirect carbonation, slurry- $\mathrm{CO}_{2}$, or carbonation with steam, among others (e.g. UliaszBocheńczyk et al., 2017, and references therein).

The goal of this investigation is to study dry and moist carbonation of a high calcium fly ash. The process is maintained at 3 different temperatures: 160,220 and $290{ }^{\circ} \mathrm{C}$ and at pressure range of $\mathrm{CO}_{2}$ and water vapor from 1 to 6 bars. The accelerating effects of the temperature, pressure and water vapor on carbonation are quantitatively evaluated.

\section{Materials and methods}

\subsection{Test materials}

Testing was performed on a high-calcium fly ash resulting from lignite burning at the Ptolemaida power station (Ptolemais, Greece), with 660 MWe installed electrical power. This power plant has 5 electric blocks equipped with electrostatic precipitators as filters. The fly ash production reaches 7.6 
Mt/yr, with only $300 \mathrm{kt}$ being recycled. The rest is being disposed at exhausted mine workings. A limited amount is used by cement companies for the manufacture of blended cements. From 2002 Ptolemais fly ash is accepted under European Standard EN 197-1(Mills, 2015). Chemical analysis of a representative sample is given in Table 1.

Table 1. Chemical analysis of the tested fly ash.

The major oxide constituents of the fly ash are: $\mathrm{SiO}_{2}(33 \%), \mathrm{CaO}(35 \%)$ and $\mathrm{Al}_{2} \mathrm{O}_{3}(13 \%)$. When compared to other HCFA, the Ptolemais fly ash is reported to have one of the world's highest $\mathrm{CaO}$ contents (Hemalatha and Ramaswamy, 2017). The crystalline phases identified in the fresh sample include lime $(\mathrm{CaO})$, quartz $\left.\mathrm{SiO}_{2}\right)$, gehlenite $\left(\mathrm{Ca}_{2} \mathrm{Al}_{2} \mathrm{SiO}_{7}\right)$, anhydrite $\left(\mathrm{CaSO}_{4}\right)$ and calcite $\left(\mathrm{CaCO}_{3}\right)$. The presence of calcite in the pre-treated sample may be due to the reaction of fresh ash with carbon dioxide in the air during storage, before the experiments were carried out. Aluminosilicate and quartz cenospheres are major constituents of the untreated fly ash.

\subsection{Experimental procedures}

Experiments were conducted on a specially designed reactor (Fig. 1). The fly ash sample is placed inside the steel reactor positioned in the oven at a maximum temperature of $300^{\circ} \mathrm{C}$. Gas flow was set to $100 \mathrm{~mL} / \mathrm{min}$. Pressure was controlled by the back-pressure regulator up to a maximum of 6 bars, in a pressurized continuous flow reactor. The system has an external water reservoir $(70 \mathrm{~mL})$ where the water vapor is being produced for the moist experiments. Heating of water is achieved with a warming tape (maximum temperature of $120^{\circ} \mathrm{C}$ ).

Experiments were carried out at three temperatures: 160,220 and $290^{\circ} \mathrm{C}$, with a heating rate of $5^{\circ} \mathrm{C} / \mathrm{min}$. Total $\mathrm{CO}_{2}$ pressure was set to 1 or 6 bar. During heating and cooling, nitrogen was used as a carrier gas, at a flow rate of $30 \mathrm{~mL} / \mathrm{min}$. After reaching the desired temperature, carbon dioxide was introduced at 20-40 $\mathrm{mL} / \mathrm{min}$, depending on the aimed pressure. For the moist experiments, temperature in 
the bubbler ranged from 90 to $120^{\circ} \mathrm{C}$ (depending on the $\mathrm{CO}_{2}$ pressure) to achieve a constant gas mixture of $\mathrm{CO}_{2} / \mathrm{H}_{2} \mathrm{O}=60 / 40$. The time of the carbonation reaction in each experiment was 2 hours. A description of the conditions of each experiment is given in Table 2.

Table 2. Experimental conditions.

Figure 1. Experimental setup for continuous flow low-pressure conditions.

\subsection{Sample characterization}

X-ray fluorescence spectroscopy (XRF) was performed on a UniQuant instrument from Thermo Fisher Scientific ${ }^{\mathrm{TM}}$, using the fusion bead method. Prior to the analysis, the fly ash sample was calcined for 2 hours at $1000^{\circ} \mathrm{C}$. The mineral composition of the investigated samples before and after reaction was determined by powder diffraction (XRD) using a Bruker D8 ${ }^{\mathrm{TM}}$ advanced diffractometer equipped with a theta-theta goniometer. The analysis was conducted in the $2 \theta$ range of 10 to $80^{\circ}$, with a step-size of $0.02^{\circ}$ and measuring time of 1 second per step. Thermogravimetric analysis was performed on a TA instruments ${ }^{\text {TM }}$ TGA G50 apparatus. About $30 \mathrm{mg}$ were heated up from 30 to $950^{\circ} \mathrm{C}$, at $10 \mathrm{deg} / \mathrm{min}$, under an $\mathrm{N}_{2}$ flow of $60 \mathrm{~mL} / \mathrm{min}$. Scanning electron microscopy (SEM) was performed with an field-emission Zeiss Neon40 ${ }^{\mathrm{TM}}$ microscope. Fourier-transform infrared spectroscopy (FTIR) analyses were carried out with a Nicolet 6700 TM instrument. IR spectra were analyzed in the $225-4000 \mathrm{~cm}^{-1}$ range. Special attention was put to extraction of the atmospheric background spectrum prior to each IR measurement.

\section{Results and discussion}

\subsection{Dry conditions - effect of temperature on carbonation}

The XRD patterns of the fresh and carbonated samples for different experimental conditions are shown in Fig. 2. The tests carried out at 160 and $220^{\circ} \mathrm{C}$ show no major differences when compared to the 
fresh sample. On the other hand, the XRD pattern of the sample carbonated at $290^{\circ} \mathrm{C}$ reflects significant changes that occurred during the carbonation reaction. Lime is consumed to favor the formation of calcite. Another interesting observation is the presence of portlandite $\left(\mathrm{Ca}(\mathrm{OH})_{2}\right)$ after the reaction. Liu et al., 2018 and Huntzinger et al., 2009 showed that formation of a stable calcium hydroxide during carbonation is possible, if the temperature of the process is maintained below $300^{\circ} \mathrm{C}$.

Figure 2. XRD analysis of samples before and after carbonation with dependence of: a) temperature, b) pressure, c) temperature, pressure and addition of water vapor. Q - quartz, $\mathrm{C}$ - calcite, $\mathrm{P}$ - portlandite, Aanhydrite, $\mathrm{G}$ - gehlenite, $\mathrm{L}$ - lime.

Accelerating carbonation by increasing the temperature is also well known (Mazzella et al., 2016). It is not straightforward, however, to provide a reaction mechanism to explain the increase of $\mathrm{CO}_{2}$ uptake at higher temperatures. One can hypothesize that at low temperatures the formation of a carbonate shell over the particles surface occurs, which was well described by other authors (Montes-Hernandez et al., 2012, 2010; Sun et al., 2008). At higher temperatures, diffusion processes are more effective and the carbonation can proceed through the bulk material. Temperature plays an important role in this process since it affects the diffusion mechanisms, reaction kinetics and thermodynamic properties. This investigation showed that increasing the temperature to $220^{\circ} \mathrm{C}$ without further increase of the $\mathrm{CO}_{2}$ pressure is not enough for the carbonation to occur, and a minimum of $290^{\circ} \mathrm{C}$ is necessary for the reaction to proceed.

Thermogravimetric data (mass losses and derivative weight change) as a function of temperature change from 30 to $950^{\circ} \mathrm{C}$ are shown in Fig.3. Derivative weight change graphs were calculated from the TGA data and they show the rate at which the sample is decomposing. As before, the results are displayed according to experimental conditions (increase of temperature, pressure and addition of water vapor). TGA analysis of the starting material shows that there is almost no mass loss in the range of $400-650^{\circ} \mathrm{C}$. This means that no $\mathrm{Ca}(\mathrm{OH})_{2}$ was present in the pre-treated sample and no hydration of the fly ash 
occurred. Figure 3. Results of TGA analysis for carbonated samples - mass loss and derivative weigh change: a) dependence of temperature, b) dependence of pressure, c) dependence of pressure and addition of water vapor, d) dependence of temperature and addition of water vapor.

All treated samples show a TG profile with a peak (mass loss) at around $400^{\circ} \mathrm{C}$, corresponding to the decomposition of $\mathrm{Ca}(\mathrm{OH})_{2}$, and a second one in the neighborhood of $650^{\circ} \mathrm{C}$, reflecting $\mathrm{CaCO}_{3}$ decomposition. It is intriguing that during the experiments the amounts of bothe calcite and portlandite are observed to increase, as can also be interpreted by the relative heights of the peaks in the XRD spectra (Fig.2). A possible explanation of this concomitant increase of the amounts of the hydroxide and carbonate phases is that, as temperature increases, some sample compounds could dehydrate and provide the water source for the formation of $\mathrm{Ca}(\mathrm{OH})_{2}$. Newly formed portlandite does not react with $\mathrm{CO}_{2}$ to form calcite as the range of temperatures used (below $300^{\circ} \mathrm{C}$ ) is too low to initiate the reaction (Montes-Hernandez et al., 2012). Comparison of the starting material with the sample carbonated under dry conditions, $290^{\circ} \mathrm{C}$ and 1 bar of $\mathrm{CO}_{2}$ (Fig.3a) provides unequivocal evidence that the amount of calcite increased and that the carbonation process was enhanced by temperature.

\subsection{Dry conditions - effect of pressure on carbonation}

Figure $2 \mathrm{~b}$ shows the XRD results for the experiments with dependence of the pressure on the fly ash carbonation for the dry experiments done at $160^{\circ} \mathrm{C}$. Conducting the experiment at 1 bar of $\mathrm{CO}_{2}$ doesn't result in appreciable changes on the XRD pattern when compared to the starting material, but increasing the pressure to 6 bars yields to significantly different results. The lime peaks almost completely disappear and a dominant calcite peak is shown at $2 \theta$ of about 29.5. Analogously to previous results on temperature dependence, portlandite also appears after $\mathrm{CO}_{2}$ treatment. It is known that at a given temperature the carbonation process depends on the carbon dioxide pressure inside the reactor (Lackner et al., 1995). The formation of new calcium carbonates under dry conditions strongly suggests that the presence of water is not a crucial factor for the fly ash carbonation to occur. Lackner et al., (1995) also showed, that direct 
carbonation is favorable from a thermodynamic point of view. Reaction of calcium oxide with carbon dioxide is more exothermic than calcium hydroxide with $\mathrm{CO}_{2}$. (-167 and $-65 \mathrm{~kJ} / \mathrm{mol}$ for the carbonation of $\mathrm{CaO}$ and $\mathrm{Ca}(\mathrm{OH})_{2}$, respectively)

Furthermore, the amount of anhydrite $\left(\mathrm{CaSO}_{4}\right)$ seems to decrease in the samples carbonated at $290^{\circ} \mathrm{C}$ and 1 bar of $\mathrm{CO}_{2}$ as well as for the samples treated at $160^{\circ} \mathrm{C}$ and 6 bars of $\mathrm{CO}_{2}$. This may indicate that the anhydrite could be an additional source of calcium for the formation of calcite.

Fig. 3 b shows the TGA analysis of experiments maintained at dry conditions, 6 bars and $160^{\circ} \mathrm{C}$. When compared with the other results, the TGA plot of this experiment shows the highest mass loss related to calcite decomposition. As in Fig.3a, the derivative weight change graph shows 2 different peaks, associated, respectively, to portlandite and calcite decomposition.

\subsection{Moist conditions - effect of addition of water vapor on carbonation}

Diffraction patterns of experiments done at $160-290^{\circ} \mathrm{C}, 1-6$ bars of $\mathrm{CO}_{2}$ and in the presence of water vapor are shown in Fig. 2c. Addition of water vapor to the experiment at 1 bar of $\mathrm{CO}_{2}$ in $160^{\circ} \mathrm{C}$ produces visible changes on the XRD pattern relative to the raw material. Previous studies have shown that the carbonation reaction between gas and solid is difficult to achieve, and that water is an important factor in the mineralization process (Matter et al., 2016). This might be associated with the catalytic properties of $\mathrm{H}_{2} \mathrm{O}$ through the creation of $\mathrm{Ca}(\mathrm{OH})_{2}$, which is more reactive than $\mathrm{CaO}$ (Manovic and Anthony, 2010). XRD results for the experiment at $160{ }^{\circ} \mathrm{C}, 1$ bar of $\mathrm{CO}_{2}$ and water vapor show a more prominent calcite peak, but the peaks of lime are still present indicating that not all of $\mathrm{CaO}$ reacted. Subsequent increase of pressure to 6 bars and then temperature to $290^{\circ} \mathrm{C}$ causes the disappearance of the lime peaks. A decrease of the amount of anhydrite is also observed, suggesting that decomposition of this sulfate could provide an additional source of calcium for the formation of calcite. 
XRD patterns of the experiments maintained at $160^{\circ} \mathrm{C}$ and 6 bars of $\mathrm{CO}_{2}\left(\right.$ Fig.2b) and $290^{\circ} \mathrm{C}$ and 6 bars of $\mathrm{CO}_{2}+$ water vapor (Fig.2c) show that almost all of the lime disappears, indicating that these conditions could be close to optimal for the complete carbonation of this type of fly ash.

Fig. $3 \mathrm{c}$ shows the results of the experiment at $160^{\circ} \mathrm{C}, 1$ bar of $\mathrm{CO}_{2}+$ water vapor, where two different de-carbonation episodes can be observed in the $650-950^{\circ} \mathrm{C}$ range. These can be attributed to different size populations of calcite in the sample, as well as the presence of small amount of amorphous calcium carbonate with a lower thermal stability (Montes-Hernandez et al., 2013). Fig.3d shows the mass losses accompanying the temperature increase for the moist experiments carried out at 6 bars of pressure, indicating that temperatures around $290^{\circ} \mathrm{C}$ or higher are more suitable for fly ash carbonation.

\subsection{Carbonation efficiency}

The calculation of the sequestration capacity and carbonation efficiency was made on the basis of TGA results, concluding that the weight losses observed at $30-105{ }^{\circ} \mathrm{C}, 105-600^{\circ} \mathrm{C}$ and $600-950^{\circ} \mathrm{C}$ are caused, respectively, by dehydration, and decomposition of calcium hydroxide and calcium carbonate (Nyambura et al., 2011; Soong et al., 2006). The amount of carbon dioxide in the untreated sample was calculated from its dry weight at $105^{\circ} \mathrm{C}$ and its mass loss between 600 and $950^{\circ} \mathrm{C}$, following

$$
\mathrm{CO}_{2}[w t \%]=\frac{\Delta m_{600-950}[g]}{m_{105}[g]} \times 100
$$

where:

$\mathrm{m}_{105}[\mathrm{~g}]$ - dry weight of the carbonated sample at $105^{\circ} \mathrm{C}$

$\Delta \mathrm{m} 600-950[\mathrm{~g}]$ - weight loss between 600 and $950^{\circ} \mathrm{C}$ for the carbonated sample

In order to calculate the weight loss of $\mathrm{CO}_{2}$ in the carbonated samples, the mass loss obtained in the pre-treated sample was deducted from the mass loss of the carbonated sample in the temperature range $600-950^{\circ} \mathrm{C}:$ 


$$
\begin{aligned}
& \Delta m_{600-950}^{\prime}[g]=\frac{m_{105}[g]-\Delta m_{600-950}[g]}{m_{105}[g]-\Delta m_{600-950}[g]} \times \Delta m_{600-950}[g] \\
& C O_{2}[w t \%]=\frac{\Delta m_{600-950}[g]-\Delta m_{600-950}[g]}{m_{105}[g]} \times 100
\end{aligned}
$$

The total calcium content (Catotal, in weight percent) and the carbonation efficiency (ろCa [\%]) were calculated respectively with equations (4) and (5) (following Huijgen et al., 2006).

$$
\begin{aligned}
& C a_{\text {total }}[w t \%]=\frac{\frac{\left(100-\mathrm{CO}_{2}[w t \%]\right)}{100} \times m_{105}[g] \times \frac{\mathrm{CaO}[w t \%]}{100} \times \frac{M_{\mathrm{Ca}}\left[\frac{g}{\mathrm{~mol}}\right]}{M_{\mathrm{CaO}}\left[\frac{g}{\mathrm{~mol}}\right]}}{m_{105}[g]} \\
& \zeta C a[\%]=\frac{C O_{2}[w t \%] \times M_{C a}\left[\frac{g}{m o l}\right]}{C a_{\text {total }}[w t \%] \times M_{C O 2}\left[\frac{g}{m o l}\right]} \times 100
\end{aligned}
$$

where:

$\mathrm{CaO}[\mathrm{wt} \%]$ - the $\mathrm{CaO}$ content in the fly ash obtained from the XRF results

$\mathrm{M}_{\mathrm{Ca}}, \mathrm{M}_{\mathrm{CaO}}, \mathrm{MCO} 2-$ molecular weights of $\mathrm{Ca}, \mathrm{CaO}$ and $\mathrm{CO}_{2}$

Table 3. Calculated values of the amount of $\mathrm{CO}_{2}\left(\mathrm{CO}_{2}[\mathrm{wt} \%]\right)$, sequestration capacity $\left(\mathrm{g} \mathrm{CO}_{2} / \mathrm{kg}\right.$ fly ash), total calcium content $($ Catotal $[\mathrm{wt} \%])$ and carbonation efficiency $\left(\zeta_{\mathrm{Ca}}[\%]\right)$ of the samples.

Table 3 shows the calculated values of the $\mathrm{CO}_{2}$ amount captured, sequestration capacity, total calcium content and carbonation efficiency of the samples. The initial content of the $\mathrm{CO}_{2}$ in the fresh samples is $1.4 \%$. The highest sequestration capacity was achieved for the dry experiment at $160{ }^{\circ} \mathrm{C}$ and 6 bars of $\mathrm{CO}_{2}$, equal to $117.7 \mathrm{~g} \mathrm{CO}_{2} / \mathrm{kg}$ fly ash. Interestingly, the sequestration capacity for the experiment with the mixture of $\mathrm{CO}_{2}$ and water vapor at 6 bars of pressure is $65.9 \mathrm{~g} \mathrm{CO}_{2} / \mathrm{kg}$ fly ash $\left(160^{\circ} \mathrm{C}\right)$ and $77.8 \mathrm{~g} \mathrm{CO}_{2} / \mathrm{kg}$ fly ash $\left(290^{\circ} \mathrm{C}\right)$. It is therefore concluded that maintaining the experiment in dry conditions with 6 bars of $\mathrm{CO}_{2}$ gives better results than treating sample with 6 bars of carbon dioxide and water vapor (partial pressures 3.5 bar $\mathrm{CO}_{2}$ and 2.5 bar of water vapor). These values are higher than the ones obtained by the 
other authors (e.g., Ji et al., 2017; Mazzella et al., 2016; Tamilselvi Dananjayan et al., 2016). This may be due to the fact that the material used in this research is substantially richer in $\mathrm{CaO}(35 \%)$ than the types of fly ash used in other investigations (4-30\%).

\subsection{FTIR analysis}

Fourier-Transform infrared spectroscopy analysis results are shown in Figure 4. An absorption band in the area of $1100 \mathrm{~cm}^{-1}$, which is a stretching vibration for $\mathrm{Si}-\mathrm{O}$, is present in all of the spectra and corresponds to the presence of quartz and remains invariable throughout the experiments (Criado et al., 2005). Also, for each treated sample spectra, when comparde to the fresh untreated samples, a high intensity absorption band at $3646 \mathrm{~cm}^{-1}$ appears, which corresponds to the presence of $-\mathrm{OH}$ in $\mathrm{Ca}(\mathrm{OH})_{2}$ (Duan et al., 2018) and confirms the results on the presence of portlandite reported earlier from XRD and TGA data. The dominant absorption band in the area of $1418-1423 \mathrm{~cm}^{-1}$ and the following one at $867-$ $873 \mathrm{~cm}^{-1}$ correlate with the presence of a C-O bond (Soong et al., 2006). Formation of carbonates is suggested by the significant increase of those peaks intensities, corresponding to calcite. Samples carbonated under dry conditions at $290^{\circ} \mathrm{C}+1$ bar of $\mathrm{CO}_{2}, 160^{\circ} \mathrm{C}+6$ bars $\mathrm{CO}_{2}$ and for the all experiments under moist conditions also show an absorption band at $1793-1799 \mathrm{~cm}^{-1}$ corresponding to calcite formation.

\subsection{Microstructural analysis}

One of the main components of the HCFA are round cenospheres mainly (Fig. 5) composed of aluminosilicate glass and quartz, but sometimes also including mullite, calcite, iron oxides, calcium silicates and sulfates (Vassilev et al., 2003; Żyrkowski et al., 2016). Cenospheres appearing in this fly ash are in a different size. Higher resolution imaging shows some small particles of square and triangular shapes, which are identified as ferrospheres. Such microstructures have been reported before and contain quartz, mullite, hematite, anhydrite and amorphous materials (Xue and Lu, 2008). 
Figure 5. SEM pictures of the samples: a) starting material, b) carbonated in $290{ }^{\circ} \mathrm{C}$ and 1 bar of $\mathrm{CO}_{2} \mathrm{c}$ ) carbonated in $160{ }^{\circ} \mathrm{C}$ and 6 bars of $\mathrm{CO}_{2}$, d) carbonated in $160{ }^{\circ} \mathrm{C}, 1$ bar of $\mathrm{CO}_{2}+$ water vapor, e) carbonated in $290{ }^{\circ} \mathrm{C}, 6$ bars pf $\mathrm{CO}_{2}+$ water vapor.

Fig.5b shows the changes experienced by cenospheres after carbonation at $290{ }^{\circ} \mathrm{C}+1$ bar of $\mathrm{CO}_{2}$. It is easily seen that the whole surface of the cenosphere is covered by small particles (of a few hundred of nanometers in size) with a characteristic rombohedral shape, attributed to newly formed carbonates. Similar particles identified as calcium carbonate are presented in the literature (e.g., Cizer et al., 2012; Galan et al., 2015; Kremer et al., 2008; Regnault et al., 2009). Fig.5c represents pictures taken after another dry experiment: $160^{\circ} \mathrm{C}+6$ bars of $\mathrm{CO}_{2}$. The cenospheres tend to be covered by larger particles than the ones shown in Fig.5b. High resolution imaging shows a group of fully grown calcite crystals as well as the newly formed carbonates. Fig.5d shows SEM pictures for the moisture experiment at $160^{\circ} \mathrm{C}$ and 1 bar of $\mathrm{CO}_{2}+$ water vapor, also demonstrating the growth of newly formed carbonates (of up to 1.4 $\mu \mathrm{m}$ in size) on the original cenospheres. The last series of pictures on Fig.5e shows the appearance of fly ash particles after a moist experiment $\left(290^{\circ} \mathrm{C}, 6\right.$ bars of $\mathrm{CO}_{2}+$ wat.vapor $)$. The cenospheres are thoroughly covered by the newly formed carbonates.

\section{Conclusions}

Direct carbonation of high-calcium Ptolemais fly ash was conducted, in the temperature range of $160-290^{\circ} \mathrm{C}$ and under 1-6 bars of $\mathrm{CO}_{2}$, in dry and moist conditions. The maximum calculated sequestration capacity achieved is $117.7 \mathrm{~g} \mathrm{CO}_{2} / \mathrm{kg}$ fly ash.

The influence on the carbonation process of three different parameters was studied: temperature, pressure and water vapor addition. All the performed analyses showed that the increase of temperature and pressure enhances carbonation, and that it is possible to achieve reaction between carbon dioxide and solid particles of fly ash without the addition of water. However, comparison of the results from dry and 
moist experiments at $160^{\circ} \mathrm{C}$ and 1 bar of $\mathrm{CO}_{2}$ indicates that water vapor also accelerates the carbonation process.

SEM imaging shows the continuous formation of carbonates on the surfaces of the fly ash cenospheres, to a lower or larger extent depending on experimental conditions. Nucleation of carbonates is favored by the presence of oxide particles at the surface of the cenospheres.

It can be concluded that the direct fly ash mineral carbonation at low pressure and moderate temperatures is an attractive process for $\mathrm{CO}_{2}$ capture and sequestration. The results indicate a high carbonation potential for industrial wastes with high calcium contents. For the Ptolemais power plant, with an annual production of 7.6 Mt of fly ash, 2.1 Mt of carbon dioxide could be captured annually under optimal conditions. Further research is needed to fully evaluate the upscaling of the laboratory experiments presented in this work.

\section{ACKNOWLEDGMENTS}

This work was partially funded by the Erasmus Mundus Joint Doctoral Programme on Environomical Pathways to Sustainable Energy Services (SELECT+), and MINECO grant ENE2015-63969-R. The authors wish to express their gratitude to Dr. Trifon Trifonov from the Barcelona Research Center in Multiscale Science and Engineering for technical assistance, and Ander Elkoro for insightful comments.

\section{REFERENCES}

Ahmaruzzaman, M., 2010. A review on the utilization of fly ash. Prog. Energy Combust. Sci. 36, 327363.

ASTM C618-05, 2005. Standard specification for coal fly ash and raw or calcined natural pozzolan for use in concrete. 
Bobicki, E.R., Liu, Q., Xu, Z., Zeng, H., 2012. Carbon capture and storage using alkaline industrial wastes. Prog. Energy Combust. Sci. 38, 302-320.

Cizer, Ö., Rodriguez-Navarro, C., Ruiz-Agudo, E., Elsen, J., Van Gemert, D., Van Balen, K., 2012. Phase and morphology evolution of calcium carbonate precipitated by carbonation of hydrated lime. J. Mater. Sci. 47, 6151-6165.

Criado, M., Palomo, A., Fernández-Jiménez, A., 2005. Alkali activation of fly ashes. Part 1: Effect of curing conditions on the carbonation of the reaction products. Fuel 84, 2048-2054.

Duan, P., Yan, C., Zhou, W., 2018. Effects of calcined layered double hydroxides on carbonation of concrete containing fly ash. Constr. Build. Mater. 160, 725-732.

EN 197-1:2011, 2011. Cement. Part 1: Composition, specifications and conformity criteria for common cement.

EN, 450-1:2013, 2012. UNE-EN 450-1:2013. Fly ash for concrete - Part 1: Definition, specifications and conformity criteria.

Fernández-Bertos, M., Simons, S.J.R., Hills, C.D., Carey, P.J., 2004. A review of accelerated carbonation technology in the treatment of cement-based materials and sequestration of CO2. J. Hazard. Mater. $112,193-205$.

Feuerborn, H., 2011. Coal Combustion Products in Europe - an update on Production and Utilisation , Standardisation and Regulation -. World Coal Ash Conf. 10-12th May, Color.

Galan, I., Glasser, F.P., Baza, D., Andrade, C., 2015. Assessment of the protective effect of carbonation on portlandite crystals. Cem. Concr. Res. 74, 68-77.

Heidrich, C., Feuerborn, H., Weir, A., 2013. Coal Combustion Products : a Global Perspective. World Coal Ash Conf. 22-25th April. Lexington, USA. 
Hemalatha, T., Ramaswamy, A., 2017. A review on fly ash characteristics - Towards promoting high volume utilization in developing sustainable concrete. J. Clean. Prod. 147, 546-559.

Huijgen, W.J.J., 2003. Carbon dioxide sequestration by mineral carbonation. Phd thesis.

Huijgen, W.J.J., Witkamp, G.-J., Comans, R.N.J., 2006. Mechanisms of aqueous wollastonite carbonation as a possible CO2 sequestration process. Chem. Eng. Sci. 61, 4242-4251.

Huntzinger, D.N., Gierke, J.S., Sutter, L.L., Kawatra, S.K., Eisele, T.C., 2009. Mineral carbonation for carbon sequestration in cement kiln dust from waste piles. J. Hazard. Mater. 168, 31-37.

International Energy Agency, 2017. Key world energy statistics.

Ji, L., Yu, H., Wang, X., Grigore, M., French, D., Gözükara, Y.M., Yu, J., Zeng, M., 2017. CO2sequestration by direct mineralisation using fly ash from Chinese Shenfu coal. Fuel Process. Technol. 156, 429-437.

Klein, F., Garrido, C.J., 2011. Thermodynamic constraints on mineral carbonation of serpentinized peridotite. Lithos $126,147-160$.

Kremer, B., Kazmierczak, J., Stal, L.J., 2008. Calcium carbonate precipitation in cyanobacterial mats from sandy tidal flats of the North Sea. Geobiology 6, 46-56.

Krevor, S.C., Lackner, K.S., 2009. Enhancing process kinetics for mineral carbon sequestration. Energy Procedia 1, 4867-4871.

Kwon, S., 2011. Mineralization for CO2 sequstration using olivine sorbent in the presence of water vapor 181.

Lackner, K.S., Wendt, C.H., Butt, D.P., Joyce, E.L., Sharp, D.H., 1995. Carbon dioxide disposal in carbonate minerals. Energy 20, 1153-1170.

Liu, W., Su, S., Xu, K., Chen, Q., Xu, J., Sun, Z., Wang, Y., Hu, S., Wang, X., Xue, Y., Xiang, J., 2018. 
CO 2 sequestration by direct gas-solid carbonation of fly ash with steam addition. J. Clean. Prod. $178,98-107$.

Manovic, V., Anthony, E.J., 2010. Carbonation of CaO-based sorbents enhanced by steam addition. Ind. Eng. Chem. Res. 49, 9105-9110.

Matter, J.M., Kelemen, P.B., 2009. Permanent storage of carbon dioxide in geological reservoirs by mineral carbonation. Nat. Geosci. 2, 837-841.

Matter, J.M., Stute, M., Snæbjörnsdottir, S., Oelkers, E.H., Gislason, S.R., Aradottir, E.S., Sigfusson, B., Gunnarsson, I., Sigurdardottir, H., Gunnlaugsson, E., Axelsson, G., Alfredsson, H.A., WolffBoenisch, D., Mesfin, K., Taya, D.F.D.L.R., Hall, J., Dideriksen, K., Broecker, W.S., 2016. Rapid carbon mineralization for permanent disposal of anthropogenic carbon dioxide emissions. Science (80-. ). 352, 1312-1314.

Mazzella, A., Errico, M., Spiga, D., 2016. CO2 uptake capacity of coal fly ash: Influence of pressure and temperature on direct gas-solid carbonation. J. Environ. Chem. Eng. 4, 4120-4128.

Mazzotti, M., Carlos, J., Allam, R., Lackner, K.S., Meunier, F., Rubin, E.M., Sanchez, J.C., Yogo, K., Zevenhoven, R., 2005. Mineral carbonation and industrial uses of carbon dioxide. IPCC Spec. Rep. Carbon dioxide Capture Storage 319-338.

Mills, S., 2015. Prospects for coal and clean coal technologies in Greece. IEA Clean Coal Cent. 2-122.

Montes-Hernandez, G., Chiriac, R., Toche, F., Renard, F., 2012. Gas-solid carbonation of Ca(OH)2and $\mathrm{CaO}$ particles under non-isothermal and isothermal conditions by using a thermogravimetric analyzer: Implications for CO2capture. Int. J. Greenh. Gas Control 11, 172-180. https://doi.org/10.1016/j.ijggc.2012.08.009

Montes-Hernandez, G., Daval, D., Chiriac, R., Renard, F., 2010. Growth of nanosized calcite through gas-solid carbonation of nanosized portlandite under anisobaric conditions. Cryst. Growth Des. 10, 
4823-4830. https://doi.org/10.1021/cg100714m

Montes-Hernandez, G., Pérez-López, R., Renard, F., Nieto, J.M., Charlet, L., 2009. Mineral sequestration of CO2 by aqueous carbonation of coal combustion fly-ash. J. Hazard. Mater. 161, 1347-1354.

Montes-Hernandez, G., Renard, F., Chiriac, R., Findling, N., Ghanbaja, J., Toche, F., 2013. Sequential precipitation of a new goethite-calcite nanocomposite and its possible application in the removal of toxic ions from polluted water. Chem. Eng. J. 214, 139-148.

Nyambura, M.G., Mugera, G.W., Felicia, P.L., Gathura, N.P., 2011. Carbonation of brine impacted fractionated coal fly ash: Implications for CO2 sequestration. J. Environ. Manage. 92, 655-664.

Papayianni, I., Tsimas, S., Moutsatsou, A., 2009. Standardization aspects concerning high calcium fly ashes. 3rd World Coal Ash, WOCA Conf. , 4-7th May, Lexington, USA. Proc.

Papayianni, J., 1993. Use of a high-calcium fly ash in blended type cement production. Cem. Concr. Compos. 15, 231-235.

Regnault, O., Lagneau, V., Schneider, H., 2009. Experimental measurement of portlandite carbonation kinetics with supercritical CO2. Chem. Geol. 265, 113-121.

Reynolds, B., Reddy, K., Argyle, M., 2014. Field Application of Accelerated Mineral Carbonation. Minerals 4, 191-207.

Soong, Y., Fauth, D.L., Howard, B.H., Jones, J.R., Harrison, D.K., Goodman, A.L., Gray, M.L., Frommell, E.A., 2006. CO2sequestration with brine solution and fly ashes. Energy Convers. Manag. 47, 1676-1685.

Sun, P., Grace, J.R., Lim, C.J., Anthony, E.J., 2008. A discrete-pore-size-distribution-based gas-solid model and its application to the $\mathrm{CaO}+\mathrm{CO} 2$ reaction. Chem. Eng. Sci. 63, 57-70. https://doi.org/10.1016/j.ces.2007.08.054 
Tamilselvi Dananjayan, R.R., Kandasamy, P., Andimuthu, R., 2016. Direct mineral carbonation of coal fly ash for CO2 sequestration. J. Clean. Prod. 112, 4173-4182.

Uliasz-Bochenczyk, A., 2007. Waste used for CO2 bonding via mineral carbonation. Gospod. Surowcami Miner. Resour. Manag. 23, 121-128.

Uliasz-Bocheńczyk, A., Pawluk, A., Pyzalski, M., 2017. The mineral sequestration of CO2with the use of fly ash from the co-combustion of coal and biomass. Gospod. Surowcami Miner. / Miner. Resour. Manag. 33, 143-156. https://doi.org/10.1515/gospo-2017-0044

UNE83420:1991, 1991. Additions for concrete. Fly ash. Specifications for fly ashes with a content more than $10 \%$ in $\mathrm{CaO}$.

Vassilev, S. V, Menendez, R., Alvarez, D., Diaz-Somoano, M., Martinez-Tarazona, M.R., 2003. Phasemineral and chemical composition of coal fly ashes as a basis for their multicomponent utilization. 1. Characterization of feed coals and fly ashes. Fuel 82, 1793-1811.

Wee, J.-H., 2013. A review on carbon dioxide capture and storage technology using coal fly ash. Appl. Energy 106, 143-151.

Xue, Q., Lu, S., 2008. Microstructure of ferrospheres in fly ashes: SEM, EDX and ESEM analysis. J. Zhejiang Univ. A 9, 1595-1600.

Żyrkowski, M., Neto, R.C., Santos, L.F., Witkowski, K., 2016. Characterization of fly-ash cenospheres from coal-fired power plant unit. Fuel 174, 49-53. 
Table 1. Chemical analysis of the tested fly ash.

\begin{tabular}{|l|r|}
\hline compound & \% content \\
\hline $\mathrm{SiO}_{2}$ & 33.11 \\
\hline $\mathrm{CaO}$ & 35.27 \\
\hline $\mathrm{Al}_{2} \mathrm{O}_{3}$ & 13.76 \\
\hline $\mathrm{MgO}$ & 3.21 \\
\hline $\mathrm{Na}_{2} \mathrm{O}$ & 1.33 \\
\hline $\mathrm{SO}_{3}$ & 4.98 \\
\hline $\mathrm{K}_{2} \mathrm{O}_{2}$ & 0.95 \\
\hline $\mathrm{Fe}_{2} \mathrm{O}_{3}$ & 5.72 \\
\hline $\mathrm{TiO}_{2}$ & 0.67 \\
\hline $\mathrm{P}_{2} \mathrm{O}_{5}$ & 0.35 \\
\hline
\end{tabular}

Figure 1. Experimental setup for continuous flow low-pressure conditions.
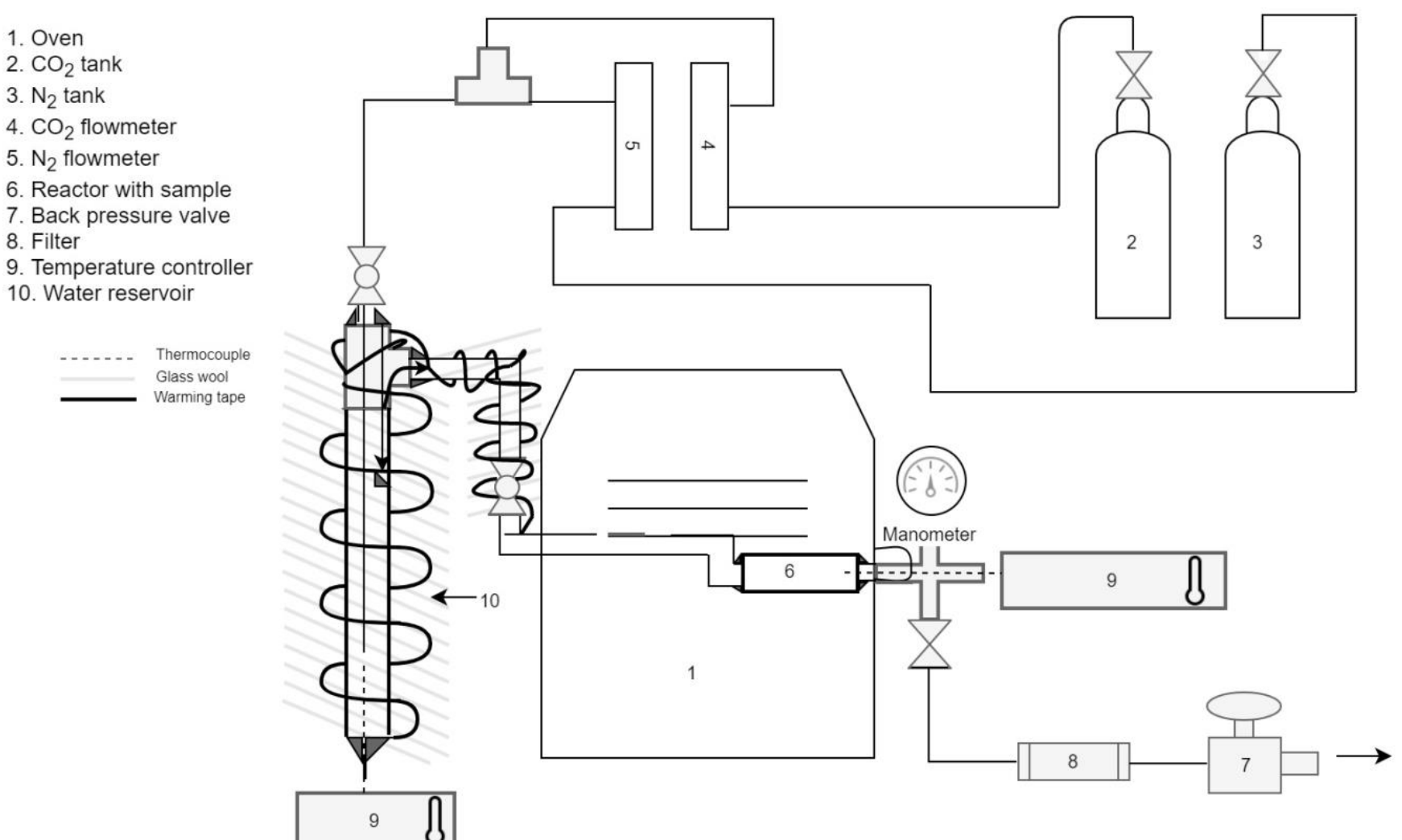

Table 2. Experimental conditions.

\begin{tabular}{|c|c|c|c|c|}
\hline no. & sample & $\mathrm{t}\left[{ }^{\circ} \mathrm{C}\right]$ & $\mathrm{p}[\mathrm{bar}]$ & $\begin{array}{c}\mathrm{d} \text { ry/moisture } \\
\text { conditions }\end{array}$ \\
\hline
\end{tabular}




\begin{tabular}{|c|c|c|c|c|}
\hline 1 & $\mathrm{Pt} / 1$ & 160 & 1 & $\mathrm{dry}$ \\
\hline 2 & $\mathrm{Pt} / 2$ & 220 & 1 & $\mathrm{dry}$ \\
\hline 3 & $\mathrm{Pt} / 3$ & 290 & 1 & $\mathrm{dry}$ \\
\hline 4 & $\mathrm{Pt} / 4$ & 160 & 1 & $\mathrm{dry}$ \\
\hline 5 & $\mathrm{Pt} / 5$ & 160 & 6 & moisture, $50 \%$ \\
water vapor \\
\hline 6 & $\mathrm{Pt} / 6$ & 160 & & moisture, $40 \%$ \\
water vapor \\
\hline 7
\end{tabular}

Table 3. Calculated values of the amount of $\mathrm{CO}_{2}$ captured $\left(\mathrm{CO}_{2}[\mathrm{wt} \%]\right)$, sequestration capacity $\left(\mathrm{g} \mathrm{CO}_{2} / \mathrm{kg}\right.$ fly ash) total calcium content (Catotal $[\mathrm{wt} \%])$ and carbonation efficiency $\left(\zeta_{\mathrm{Ca}}[\%]\right)$ of the samples.

\begin{tabular}{|c|c|c|c|c|c|}
\hline sample & $\begin{array}{c}290{ }^{\circ} \mathrm{C}, 1 \\
\text { bar } \mathrm{CO}_{2}\end{array}$ & $\begin{array}{c}160{ }^{\circ} \mathrm{C}, 6 \\
\text { bars } \mathrm{CO}_{2}\end{array}$ & $\begin{array}{c}160{ }^{\circ} \mathrm{C}, 1 \text { bar } \\
\mathrm{CO}_{2}+\text { water } \\
\text { vapor }\end{array}$ & $\begin{array}{c}160{ }^{\circ} \mathrm{C}, 6 \text { bars } \\
\mathrm{CO}_{2}+\text { water } \\
\text { vapor }\end{array}$ & $\begin{array}{c}290{ }^{\circ} \mathrm{C}, 6 \text { bars } \mathrm{CO}_{2}+ \\
\text { water vapor }\end{array}$ \\
\hline $\mathrm{CO}_{2}[\mathrm{wt} \%]$ & 7.56 & 11.77 & 4.16 & 6.59 & 7.78 \\
\hline $\begin{array}{c}\mathrm{g} \mathrm{CO}_{2} / \mathrm{kg} \\
\text { fly ash }\end{array}$ & 75.6 & 117.7 & 41.6 & 65.9 & 23.23 \\
\hline \begin{tabular}{c}
$\mathrm{Catotal}[\mathrm{wt} \%]$ \\
\hline$\zeta_{\mathrm{Ca}}[\%]$
\end{tabular} & 23.30 & 22.22 & 24.14 & 23.53 & 30.44 \\
\hline
\end{tabular}

Figure 2. XRD analysis of samples before and after carbonation with dependence of: a) temperature, b) pressure, c) temperature, pressure and addition of water vapor. $\mathrm{Q}$ - quartz, $\mathrm{C}$ - calcite, $\mathrm{P}$ - portlandite, $\mathrm{A}$ anhydrite, $\mathrm{G}$ - gehlenite, $\mathrm{L}$ - lime.

a) 


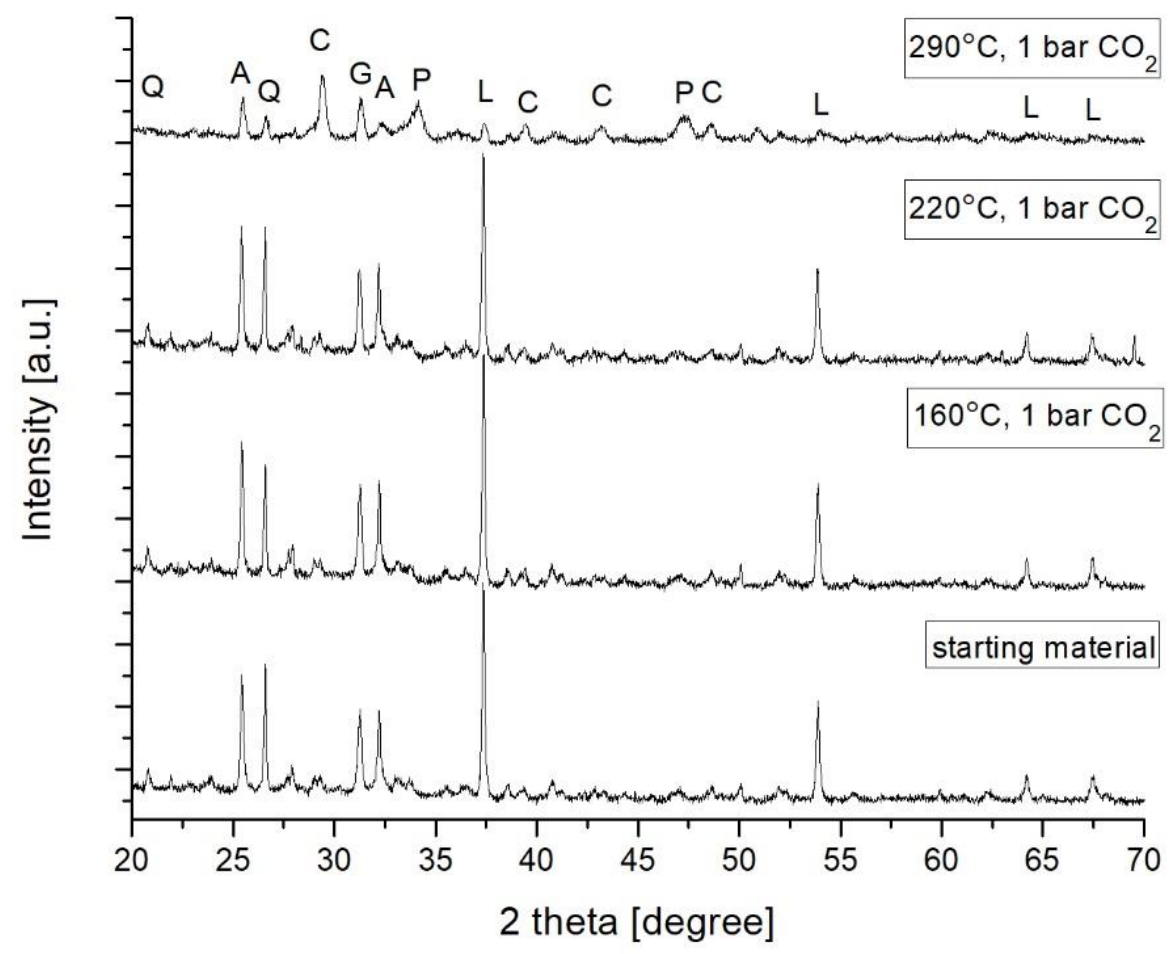

b)

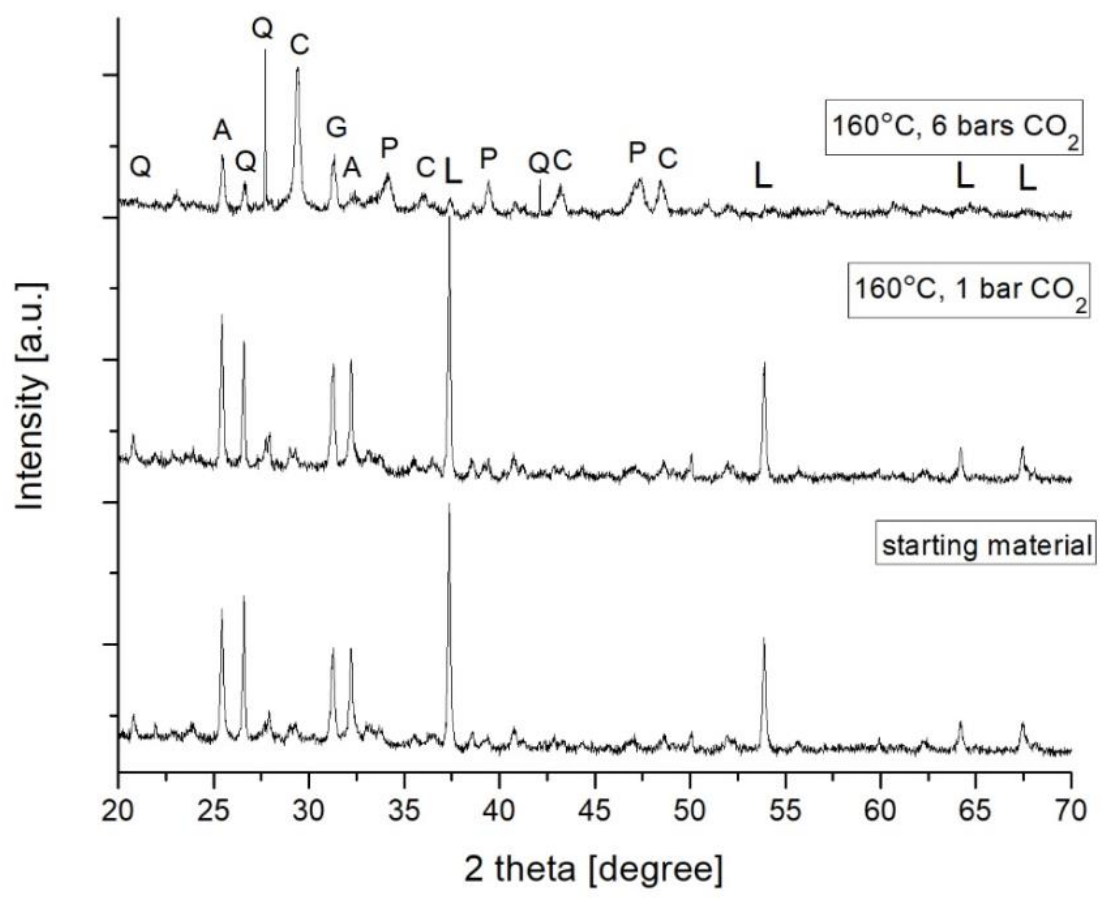

c) 


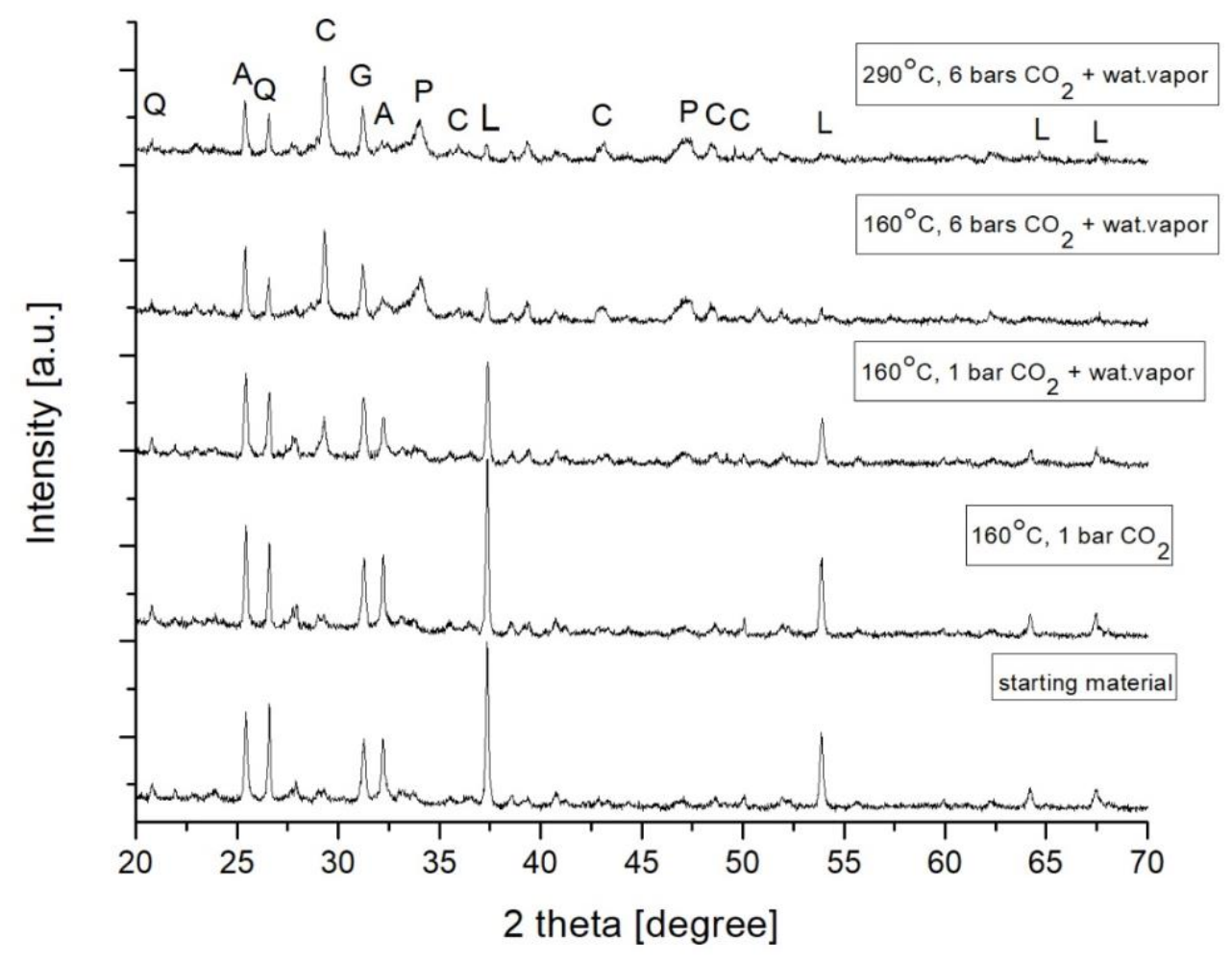

Figure 3. Results of TGA analysis for carbonated samples - mass loss and derivative weigh change: a) dependence of temperature, b) dependence of pressure, c) dependence of pressure and addition of water vapor, d) dependence of temperature and water vapor.

a)
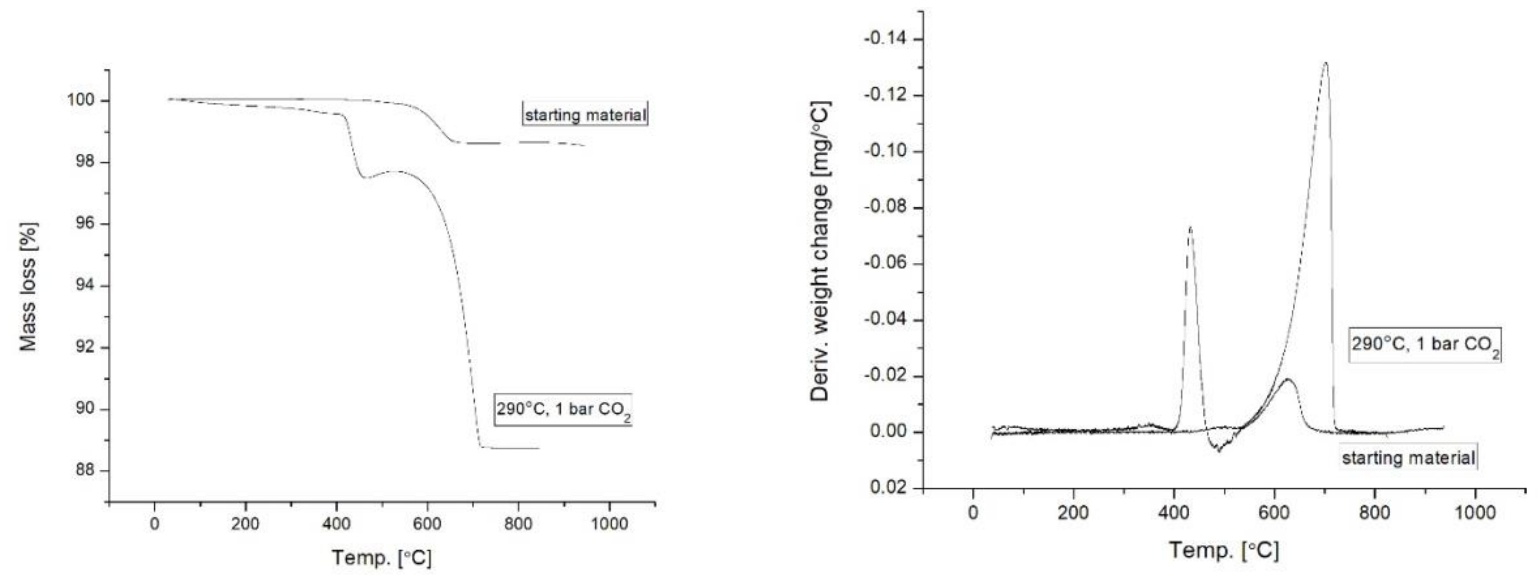
b)
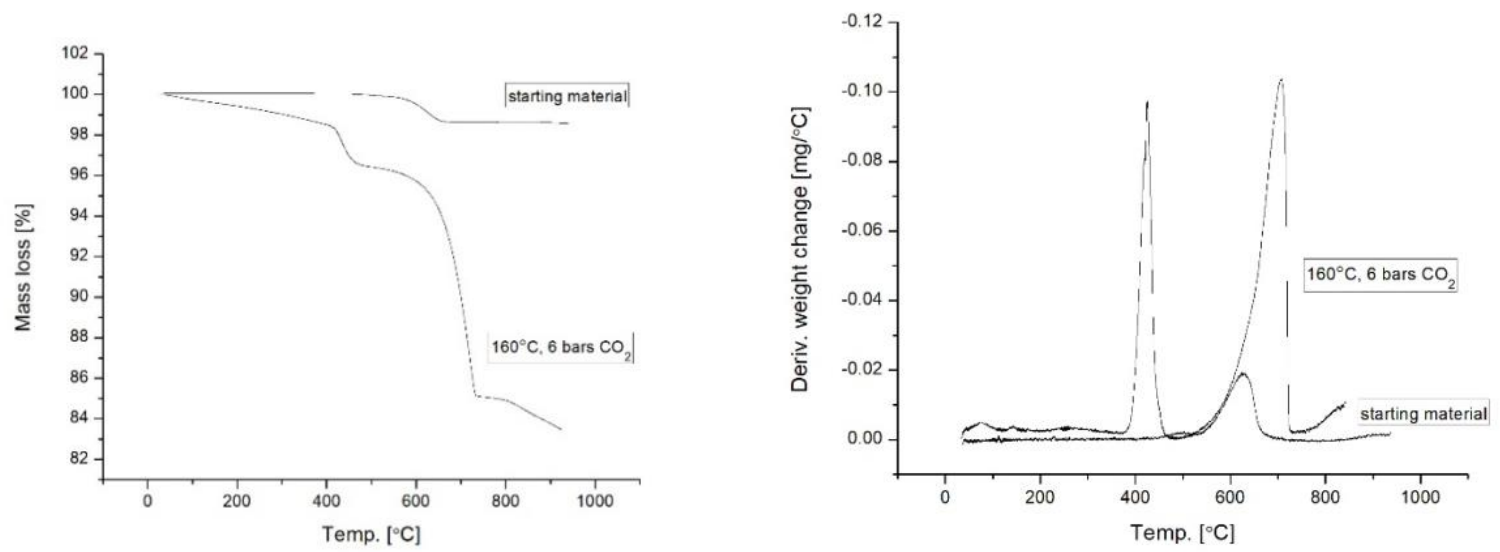

c)
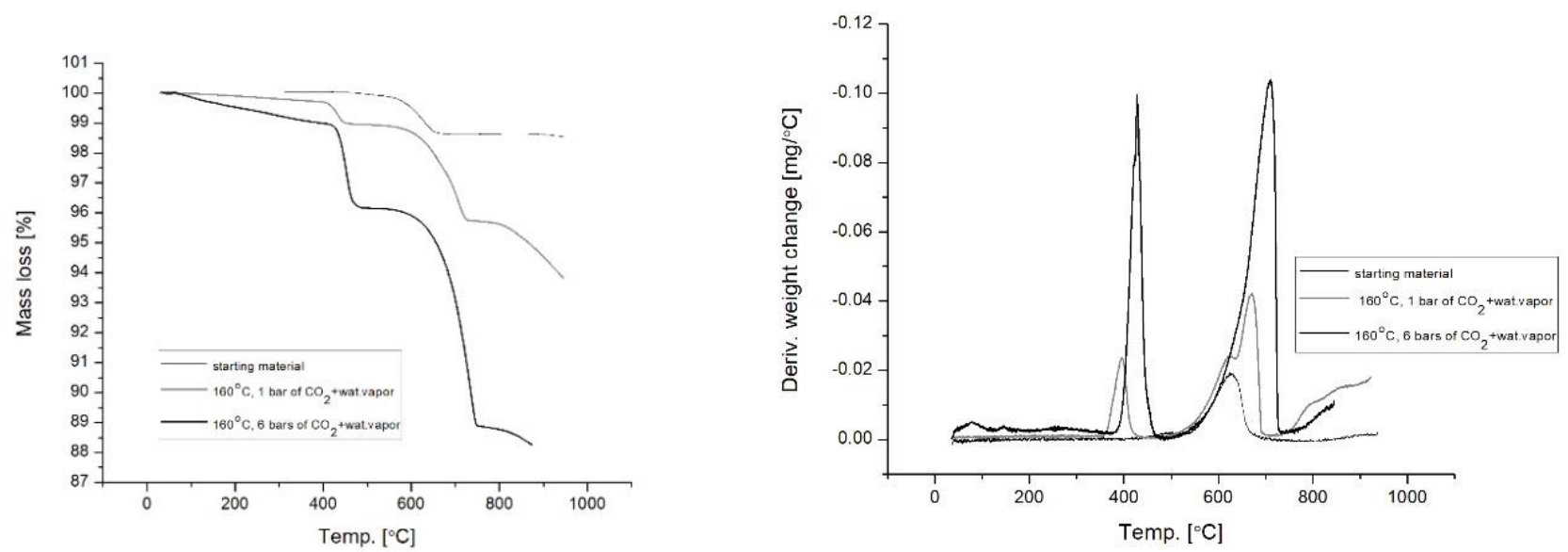

d) 

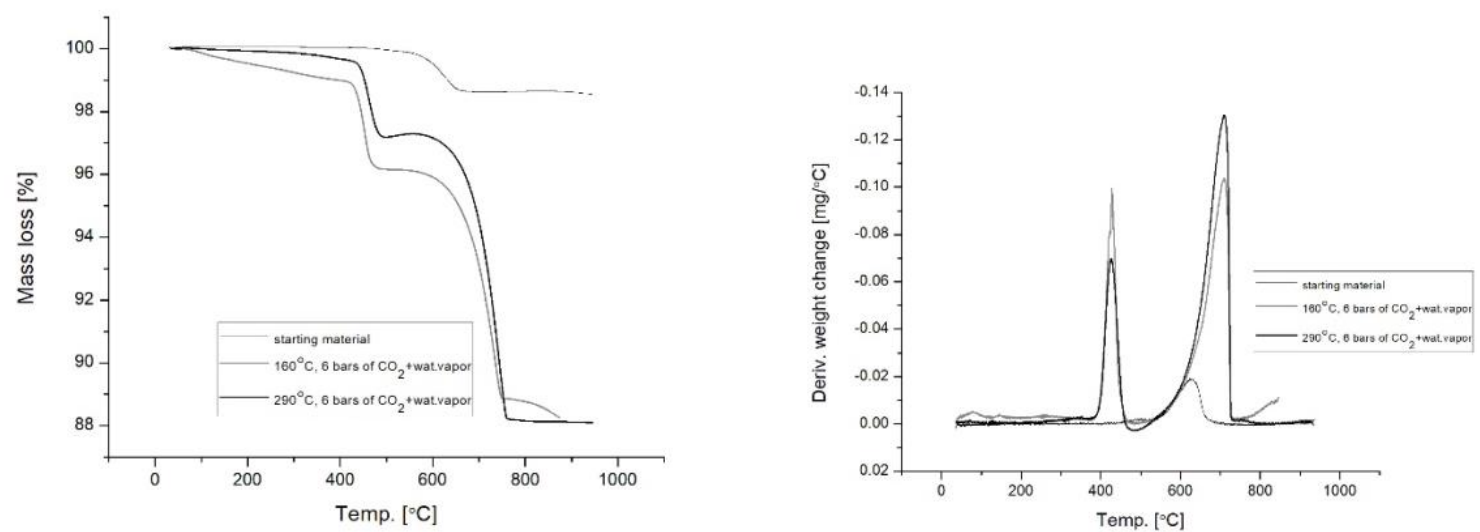

Figure 4. Results of IR analysis for carbonated samples: a) dependence of temperature, b) dependence of pressure, c) dependence of pressure and addition of water vapor, d) dependence of temperature and water vapor.

a)

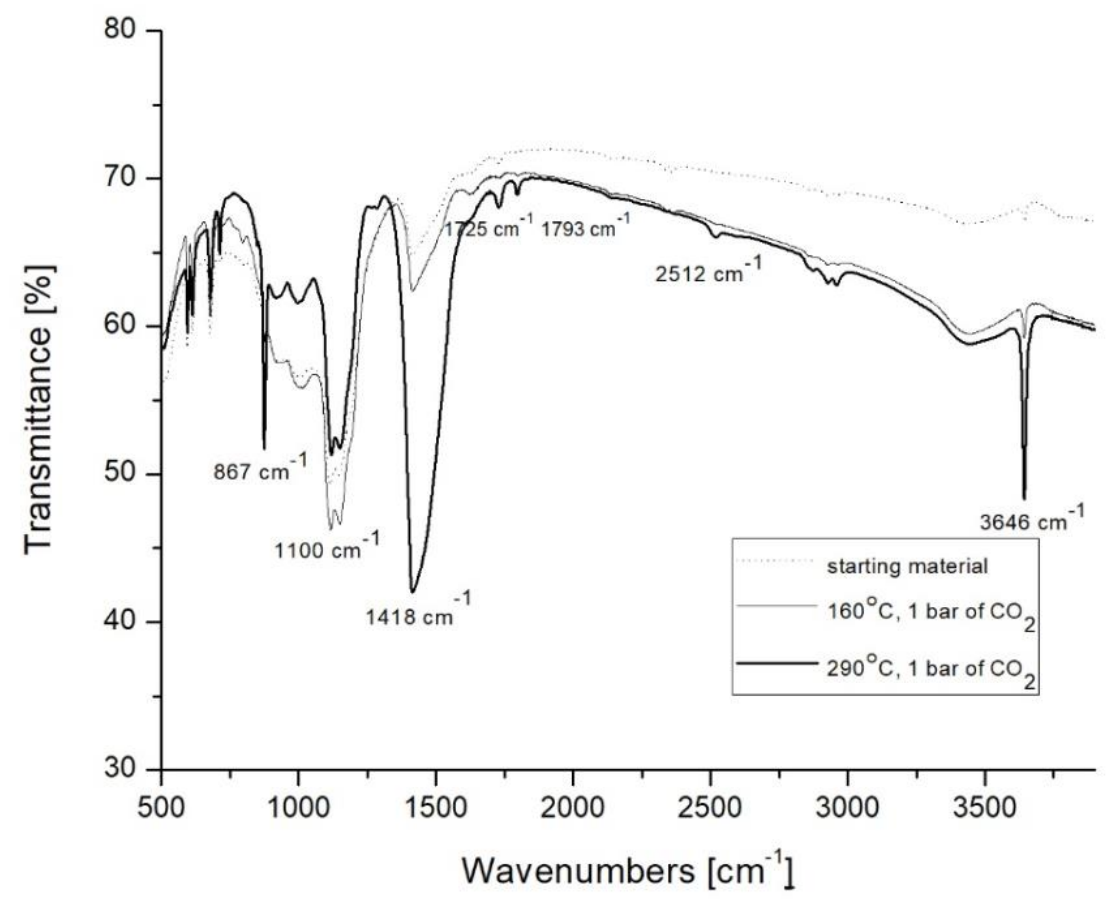




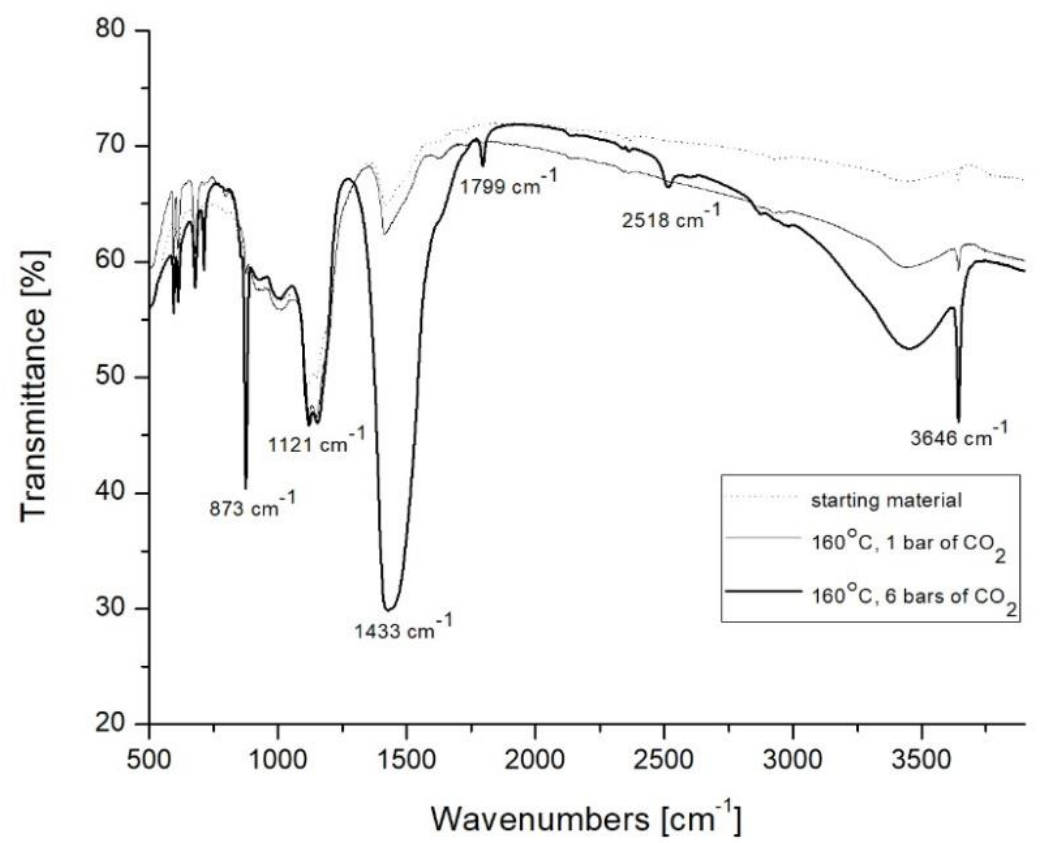

c)

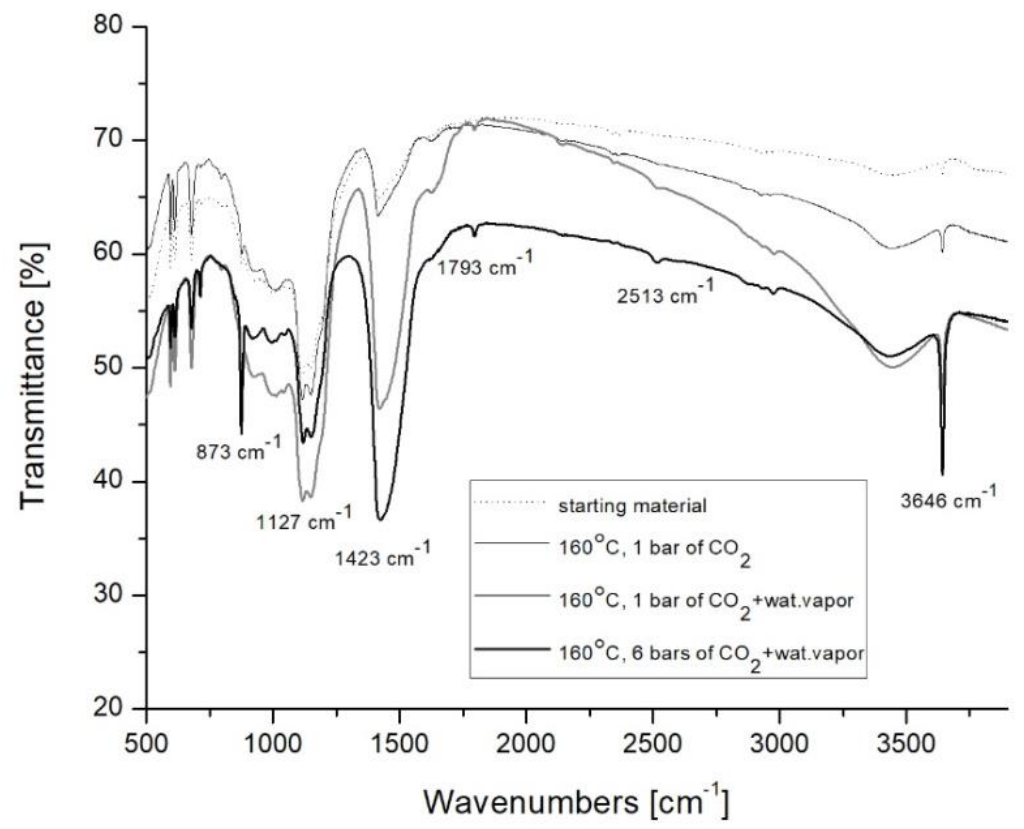

d) 


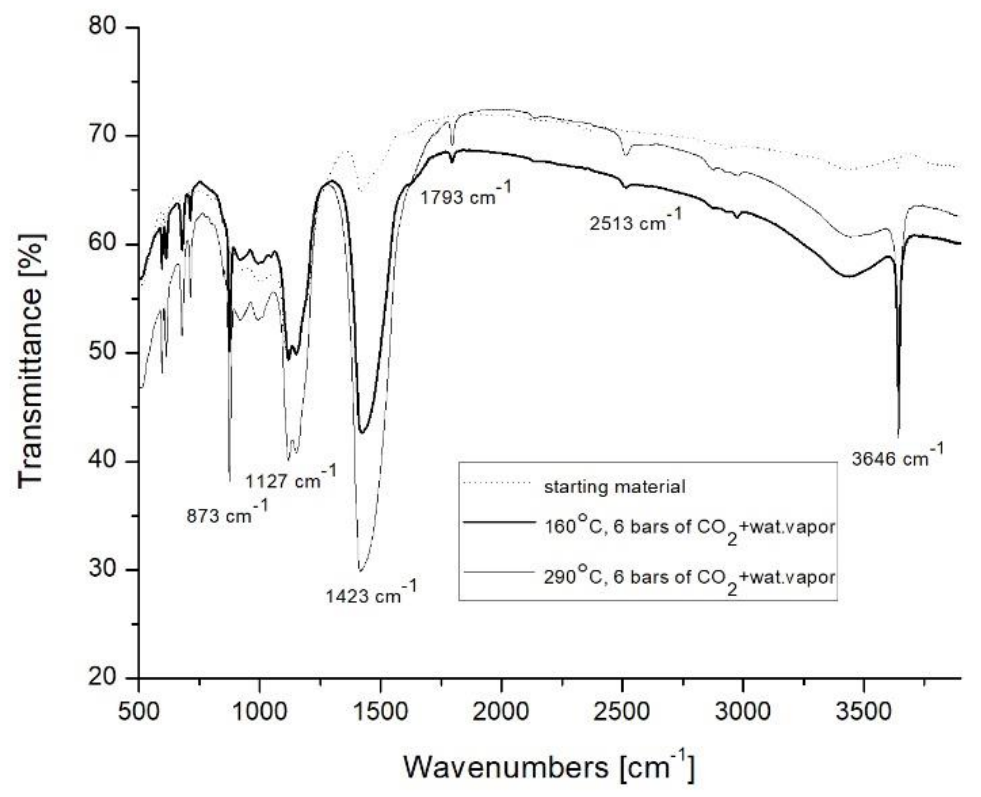

Figure 5. SEM pictures of the samples: a) starting material, b) carbonated in $290{ }^{\circ} \mathrm{C}$ and 1 bar of $\mathrm{CO}_{2} \mathrm{c}$ ) carbonated in $160^{\circ} \mathrm{C}$ and 6 bars of $\mathrm{CO}_{2}$, d) carbonated in $160^{\circ} \mathrm{C}, 1$ bar of $\mathrm{CO}_{2}+$ water vapor, e) carbonated in $290{ }^{\circ} \mathrm{C}, 6$ bars pf $\mathrm{CO}_{2}+$ water vapor.

a)
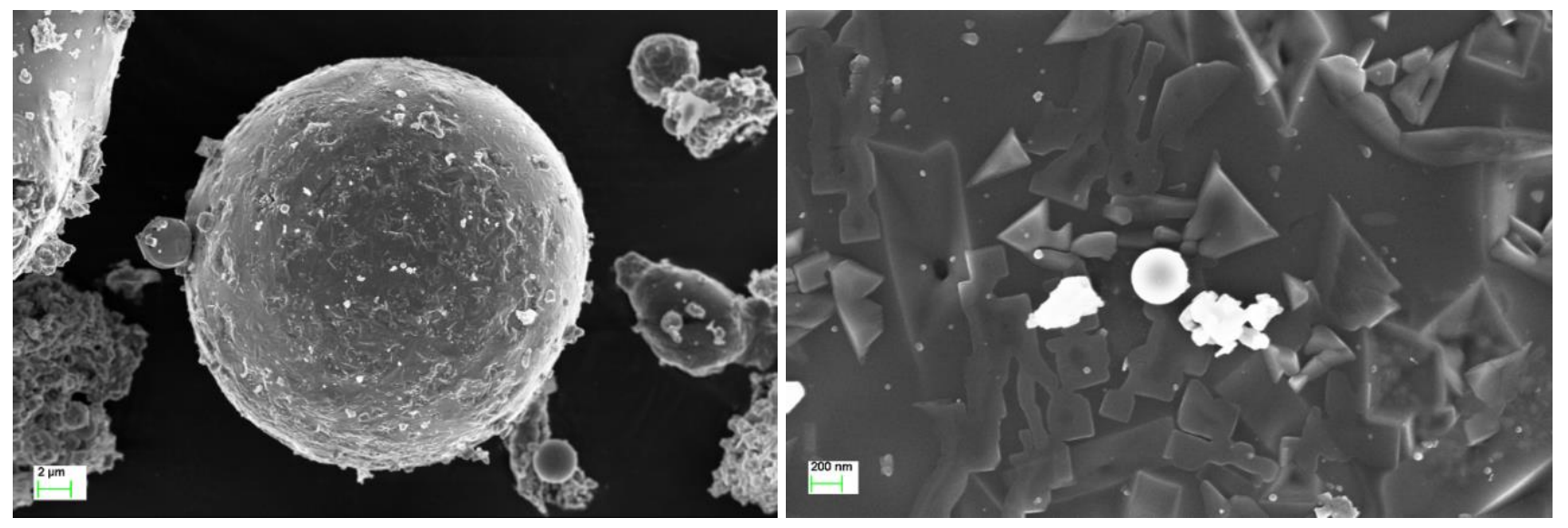

b) 

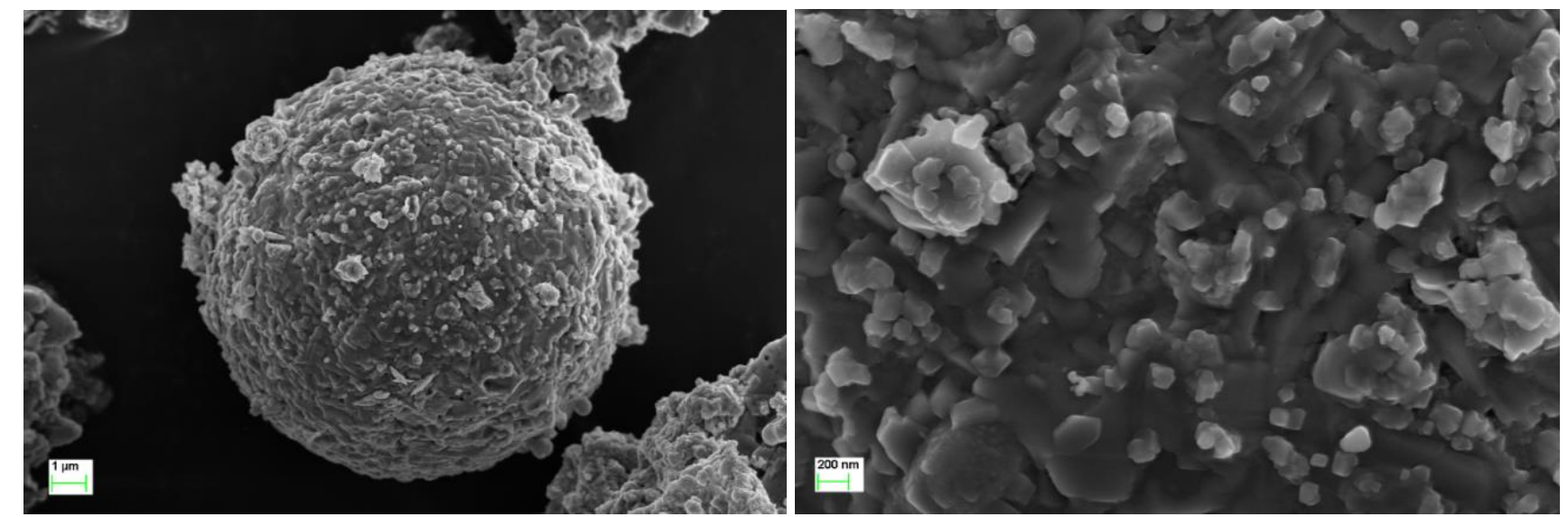

c)
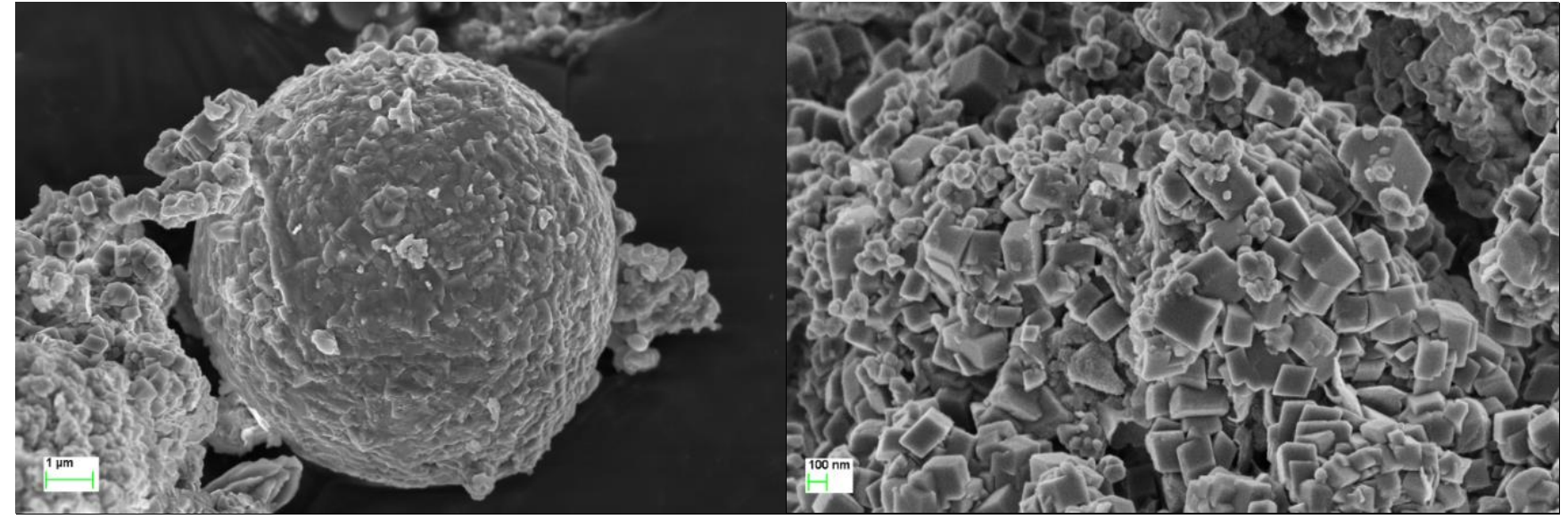

d)
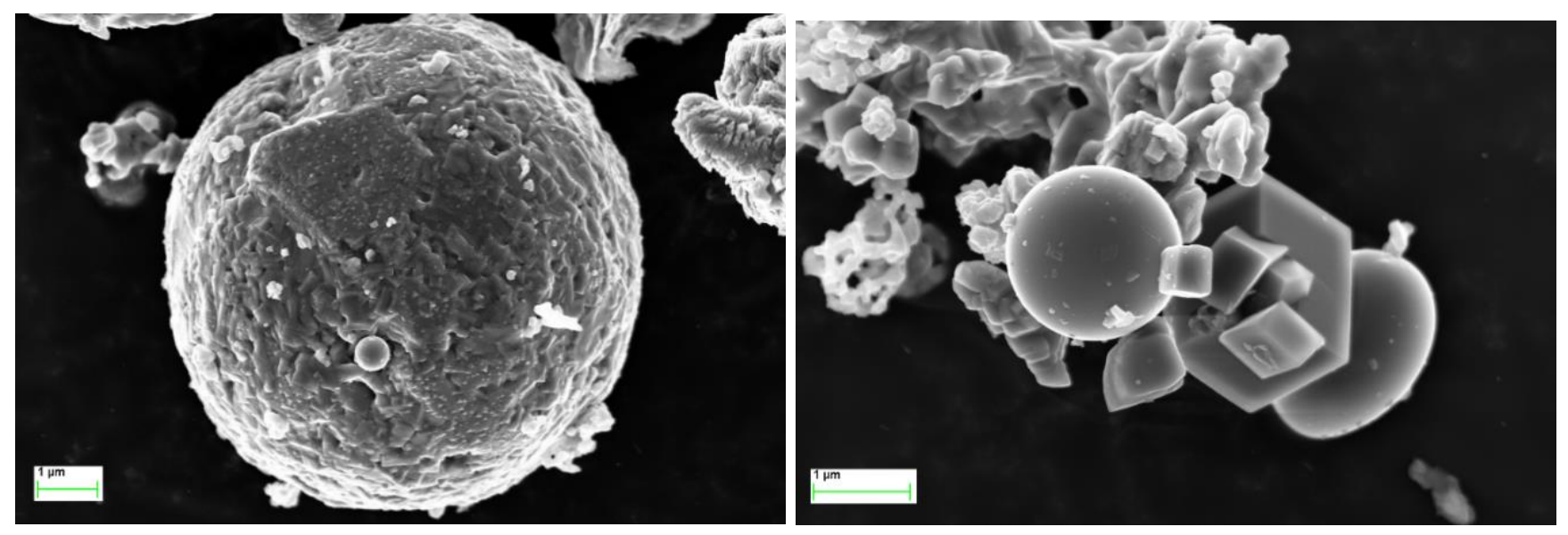

e) 

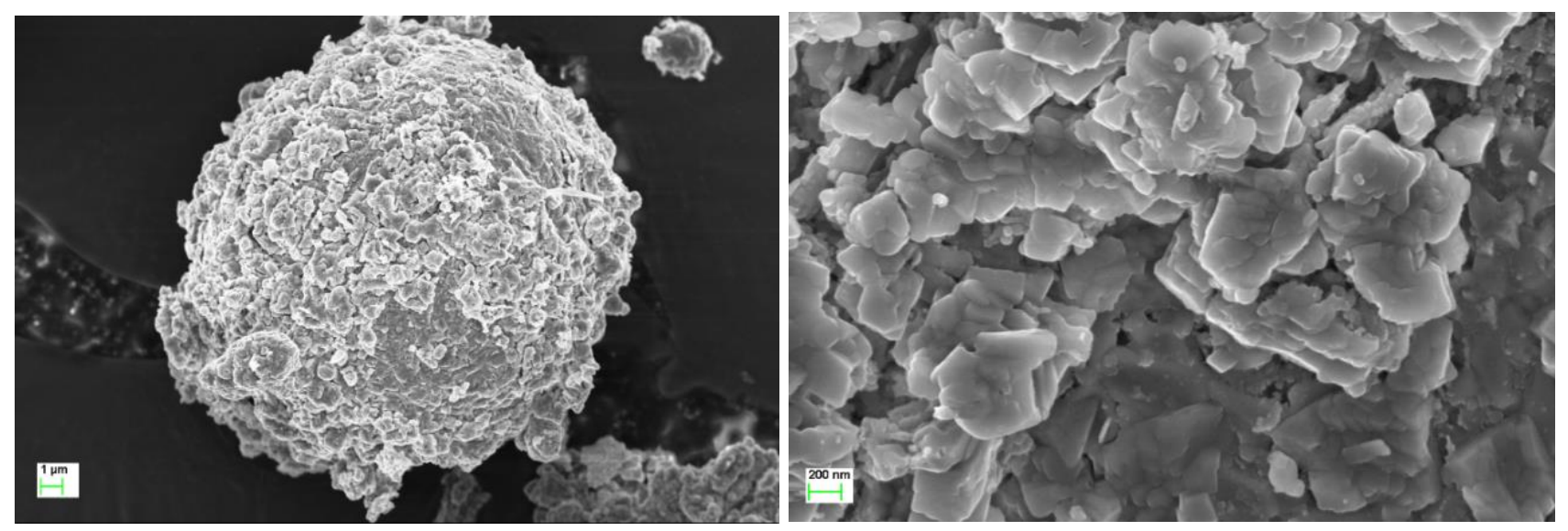